\title{
An Alternative to Antibiotics: Selected Methods to Combat Zoonotic Foodborne Bacterial Infections
}

\author{
Ewelina Łojewska ${ }^{1} \cdot$ Tomasz Sakowicz $^{1}$
}

Received: 11 January 2021 / Accepted: 20 September 2021 / Published online: 9 October 2021

(c) The Author(s) 2021

\begin{abstract}
Pathogenic bacteria contaminating food or animal feed cause serious economic losses in the health sector as well as is in the agriculture and food industry. The development of bacterial resistance due to the misuse of antibiotics and chemicals, especially in the farm industry, can bring dangerous effects for the global population therefore new safe biological antimicrobial solutions are urgently needed. In this paper, we investigate biological alternatives to antibiotics against foodborne pathogens. The most promising alternatives include antimicrobial proteins, bacteriophages, probiotics, and plant-based substances. Each described group of substances is efficient against specific foodborne bacteria and has a preferred use in an explicit application. The advantages and drawbacks of each method are outlined in the final section. Biological antibacterial solutions are usually easily degradable. In contrast to antibiotics or chemical/physical methods, they are also far more specific. When introducing new antibacterial methods it is crucial to check their safety and ability to induce resistance mechanisms. Moreover, it is important to assess its activity to inhibit or kill in viable but nonculturable cells (VBNC) state and biofilm forms. VBNC bacteria are considered a threat to public health and food safety due to their possibility of remaining viable and virulent. Biological alternatives to antibiotics complete the majority of the advantages needed for a safe and efficient antimicrobial product. However, further research is necessary to fully implement those solutions to the market.
\end{abstract}

\section{Introduction}

Bacterial foodborne diseases are a serious threat when it comes to health safety. WHO states that the global median number of bacterial diseases is 360 million per year, $60 \%$ of which are foodborne diseases. A median number of 260,000 people die each year globally due to bacterial foodborne diseases [1]. Even though bacterial foodborne diseases can be prevented, they still cause a health and economic burden for every country in the world. The economic cost of all foodborne diseases in the USA is estimated at approximately \$10-83 billion annually; therefore, we can assume that at least half of this cost is caused by bacterial pathogens [2].

Foodborne bacterial pathogens are usually strictly connected to animal breeding. For example, Salmonella and Campylobacter are often transmitted from poultry;

Ewelina Łojewska

ewelina.lojewska@biol.uni.lodz.pl

1 Department of Molecular Biotechnology and Genetics, Faculty of Biology and Environmental Protection, University of Lodz, Building A, Banacha 12/13 Street, 90-237 Lodz, Poland moreover, these bacteria repeatedly display antimicrobial resistance phenotypes [3,4]. In agriculture, pathogenic foodborne bacteria can affect not only the final product but also animal health and production efficiency. For the above reasons, it seems that finding an efficient method to control foodborne bacterial pathogens at the early stages of food production (e.g., during animal breeding), could also decrease the incidence of human infections [5]. For years, antibiotics have been widely used for this purpose. However, evidence of bacteria gaining resistance to antibiotics came to light, and currently, after many years of usage, residues of antibiotic drugs are being detected in meat, milk, and egg products [6]. Many of the antibiotics that have been administrated is excreted in an active form. Furthermore, there are serious concerns about the transfer of resistance genes from farms to manure, soil, water, and finally to the environment of humans [7]. Such a scenario leads to an increase in antibiotic-resistant bacteria and then also to antibioticresistant pathogens transmitted to humans via the environment or food. For example Salmonella enterica ser. Typhi infections resistant to ciprofloxacin reached $74 \%$ in 2017 from $22 \%$ in 1990, while Shigella infections have increased from less than 5\% in 2013 to the $24 \%$ in 2017 [8]. According 
to the CDC report from 2019 foodborne bacteria are on the highest rise among all resistant bacteria in the last 5 years [6]. Therefore, current law concerning agricultural production significantly limits the use of antibiotics for the breeding industry [9], especially in the EU and the USA. However, in many other countries, particularly developing ones, there is still a lack of antibiotic usage regulations which can lead to the deepening of the global problem [10, 11]. Finding an efficient alternative to antibiotics that could boost the first stages of food production is an urgent need. Importantly, such treatment must be feasible and applicable across large groups of livestock. Furthermore, it should not be toxic to humans. The objectives of the review were to identify and validate the most promising natural non-antibiotic biological methods against foodborne pathogens and to describe their efficiency based on up-to-date experimental findings. Moreover, current consumer choices are progressively more conscious and aimed at natural and ecological food production methods [12]. The Discovery of relevant methods and approaches that have been successful and collecting information about current research projects can help to establish a foundation on which future research can be based. For the study, few search engines were used: Web of Science, Scopus, and Google Scholar. The research database was built by the usage of keywords such as biological alternatives to antibiotics, non-antibiotic biological agents, antibiotic-resistant foodborne pathogens.

The literature on the subject indicates a variety of novel methods to fight against bacteria such as antimicrobial proteins (AMPs), plant-derived antimicrobial substances, probiotics, and bacteriophages. Due to the highest occurrence of research dedicated to those groups of substances authors decided to choose them as currently the most promising methods against foodborne bacterial infections both prevention and treatment. Currently, biological alternatives to antibiotics are increasingly used in prevention and therapies against bacterial pathogenic diseases which are reflected in many scientific publications, clinical trials, and commercialized products described in the article.

\section{Antimicrobial Proteins}

Naturally occurring AMPs have been found in almost every species and are one of the first forms of organism defense against pathogens. AMPs are a very diverse group of molecules, due to that different classification models exist depending on different features such as structure, mechanism of action, or activity. The majority of them have antibacterial activity on which this review will focus. Mechanism of action is a key element in understanding and facilitating further development of AMPs based drugs. There are two major mechanisms: immune modulation and direct killing. Direct killing can be split into membrane killing and non-membrane killing. Membrane killing is also divided into receptor and non-receptor interactions. Bacterial AMPs usually have an affinity to the receptor molecules while most of the eukaryotes AMPs do not need specific receptors to disrupt bacterial membrane. AMPs form pores in a membrane, causing cell death, preceded by leakage of cellular solutes. Their non-receptor mechanism of action also minimizes the risk of developing resistance by bacteria. Bacterial and eukaryotic AMPs share some features, such as small size (15-50 amino acids), positive charge (from +2 to +9 ) with a significant share of cationic arginine or lysine residues, and are hydrophobic (about 50\%) or amphiphobic. Their properties facilitate interactions with the negatively charged bacterial cell wall. In the case of Gram-positive bacteria, peptides interact with lipoteichoic acid and peptidoglycan, displacing divalent ions and at the same time providing binding to the negatively charged lipids located at the outside of the cell membrane. In the case of Gram-negative bacteria, AMPs interact with lipopolysaccharides (LPS) and also displace divalent ions. Eukaryotic AMPs have a broader spectrum of antibacterial activity in comparison to bacterial AMPs and they are much less cytotoxic toward eukaryotic cells. They act as the first natural defense; therefore, the highest expression of AMPs is found in the tissues in contact with the environment such as skin, eyes, respiratory epithelium, lungs, intestines, and urinary tract. Moreover, antimicrobial peptides were also isolated from animals, insects, plants, fungi, etc. The diversity of AMPs along with their antibacterial properties could be utilized in the application of these bioactive molecules as promising drug candidates in the pharmaceutical industry. Those peptides can also act against antibiotic-resistant viable but not culturable (VBNC) pathogens, for example, EmPis-1L peptide efficiently eliminates the antibiotic-resistant VBNC state cells of foodborne pathogenic bacteria such as Escherichia coli $\mathrm{O} 157$ and Vibrio parahaemolyticus OS4 [13]. AMPs have also the potential to eradicate bacterial biofilms [14]. Prominent examples of eukaryotic AMPs with therapeutic potential against foodborne pathogens are 11-37 and $\alpha$-defensin [15], salmine [16], lactoferrin [17], protamine [18], casecidin and isracidin [19], fibrinogen [20], pleurocidin [21], lb-AMP1 peptide [22], $\alpha$-poly-l-lysine (poly-lys), $\alpha$-poly-L-arginine (poly-arg) and protamines from herring sperm (clupeine sulfate) and salmon sperm (salmine sulfate) [23].

\section{Bacteriocins}

Bacterial AMPs gained the greatest popularity among AMPs therefore it was needed to describe them as a separate subgroup of potential alternatives. Bacteriocins vary highly in their mode of action and structure; therefore, many different classes and subclasses occur, although in Table 1 we propose one of the simplest and most popular classifications. 
Table 1 Simplistic classification of bacteriocins

\begin{tabular}{|c|c|}
\hline Type & Features \\
\hline \multicolumn{2}{|c|}{ Origin from Gram-positive Bacteria } \\
\hline Class I & $\begin{array}{l}\text { Thermostable, polycyclic peptides with a molecular weight } \\
\text { of less than } 5 \mathrm{kDa} \text {, contain in their structure unusual amino } \\
\text { acids: lanthionine, 3-methyllanthionine, dehydroalanine }\end{array}$ \\
\hline
\end{tabular}

Class II Non-non-antibiotic bacteriocins-thermostable proteins with a mass less than $10 \mathrm{kDa}$, divided into 4 subclasses

Mechanism of action

mass less than $10 \mathrm{kDa}$, divided into 4 subclasses

Type A lantibiotics-elongated, flexible molecules whose action is based on the formation of pores in the cytoplasmic membrane of sensitive bacterial cells

B-type lantibiotics-rigid, globular molecules with diverse mechanisms of activity. The best known is nisin (Lactococcus lactis), which has a bactericidal effect on Staphylococcus aureus, Listeria monocytogenes, prevents the development of spores, inhibits the growth of vegetative cells Bacillus, Clostridium

II A-Pediocin-like bacteriocins—-have strong activity against Listeria ssp.

II B-Two-peptide bacteriocins - to achieve the bactericidal activity, the simultaneous action of both peptides is required

II C - Sec-dependent bacteriocins—are secreted using proteins sec

II D-Bacteriocins differing in structure, mechanism of action, and secretion from previous

\begin{abstract}
Class III High molecular bacteriocins-mainly produced by Lactobacillus and Enterococcus are heat-inactivated

Class IV Protein-lipid and protein-carbohydrate complexes require the presence of the lipid or carbohydrate portion in the molecule to achieve full activity
\end{abstract}

Origin from Gram-negative bacteria

Colicins Majority of them found in E. coli strains

Proteins between 20 and $90 \mathrm{kDa}$ in size

Microcins Small, composed of relatively few amino acids
Often consist of a receptor-binding domain, a translocation domain, and a cytotoxic domain

Further subclassification can be based on their mechanisms of action either import mechanism (group A and B) or cytotoxic mechanism (nucleases, pore-forming, M-type, L-type)

Peptides with a mass less than $5 \mathrm{kDa}$-post-translational modified, attack intracellular structures

Peptides with a molecular weight of $7-10 \mathrm{kDa}-$ not post-translational modified, they work by damaging the cell membrane
Lately, it is concluded that bacteriocins should be defined as ribosomally produced multi-functional substances of proteinaceous nature, with pronounced antimicrobial activity at certain concentrations [24]. They are used by bacteria usually to inhibit other closely related species. They have useful features such as the capability of the rapid killing of bacteria and high potency. They often act at picto- or nanomolar concentrations in contrast to other (eukaryotic) AMPs that require higher molar concentrations. Bacteriocins have a narrower spectrum of activity in comparison to antibiotics and eukaryotic AMPs. They usually act only on a few genera or species closely related to the producer. Due to that fact, they have great potential as a new method for fighting with pathogens while keeping alive the probiotic and commensal bacteria. Other advantages of bacteriocins include activity in a wide $\mathrm{pH}$ range and tolerance of high thermal stress. Bacteriocins can be considered efficient antimicrobial agents in past used mainly for food preservation. Currently, the evolution of genetic engineering and proteomics gave access to the development of bacteriocin-based alternatives to antibiotics, especially for the resistance to antibiotic pathogenic bacteria strains.

Currently, bacteriocins are frequently used as antimicrobial preservatives in food products, in three main forms: bacteria cultures, food products containing bacteriocins in the form of crude fermentate, and finally as partially purified proteins. The bacteria cultures producing a chosen bacteriocin and crude fermentates of bacteriocins are supplemented during food production. Commercial examples of such solutions are BioSafe ${ }^{\mathrm{TM}}$ (bacteriocin: Nisin A), Bactoferm ${ }^{\mathrm{TM}}$ F-LC (sakacin A and pediocin PA-1/AcH), ALCMix1 (plantaricin and carnocin), Bactoferm ${ }^{\mathrm{TM}}$ (Leucocin or Sakacin), MicroGARD ${ }^{\circledR}$ (a mixture of different bacteriocins) [15]. A flagship example of usage of bacteriocin in the inhibition of foodborne pathogens is nisin Z, also in a purified form (commercial product: Nisaplin $\AA$, containing $2.5 \%$ nisin) [25]. Research showed that orally administered milk with probiotic bacteriocin-producing strains of lactic acid bacteria (LAB), reduced the severity and duration of diarrhea related to Salmonella infection in pigs [26]. Bacteriocin pediocin 
PA-1 reduced vancomycin-resistant Enterococci (VRE) colonization of the intestine of mice [27]. Microcin J25 was shown to reduce infection caused by Salmonella in a mouse model [28]. Importantly, bacteriocins can effectively fight biofilm formation [29], for example, bacteriocin derived from Lactobacillus brevis DF01 can inhibit the growth of biofilms of two popular foodborne pathogens $E$. coli and $S$. enterica ser. Typhimurium [30]. Moreover, current publications report the effectiveness of $\mathrm{LAB}$ producing bacteriocins against antibiotic-resistant Staphylococci [31]. Synergistic use of bacteriocins together with bacteriophages is an interesting possibility, research showed the cooperation of those two therapies against food pathogens, e.g., L. monocytogenes [32]. What is interesting, scientists described also the activity of new genetically engineered bacteriocins-integrated enterocin CRL35 and microcin V against clinically isolated enterohemorrhagic E. coli and L. monocytogenes [33], these findings suggest a further broad potential for the construction of novel bacteriocin antimicrobials. Previous works have shown that AMPs can be produced in plants thanks to currently available genetic engineering tools, this gives a new opportunity for the efficient production of them [34]. AMPs genes expressed in the edible plants could be also an alternative to the addition of antibiotics or other antimicrobials to the feed. Optimization of such technology would allow the prevention and treatment of bacterial foodborne infections, especially in livestock.

As described above success stories highly increased interest in bacteriocins as safe alternatives for antibiotics. The number of AMPs was positively tested for antimicrobial properties against foodborne pathogens, although a continuation of research is necessary to deploy them on a greater scale for their utilization as alternatives to antibiotics. Moreover, it is crucial to evaluate the possibility of increasing bacterial resistance to AMPs. The development of antimicrobial peptides for clinical and commercial use still has some weaknesses, such as high production costs. Yet novel and efficient methods of peptide and protein production, e.g., expression of recombinants in plant cells are described with promising results. Moreover, current studies on bacteriocins are very optimistic and suggest that bio-engineering methods can lead to even more efficient and dedicated applications of bacteriocins. Proteolytic digestion in the intestinal tract may affect bacteriocin activity, due to this their delivery procedures are one of the most challenging parts of their application. For example, the development of micelle nanocarriers for nisin can broaden the applicability of foodborne pathogens treatment [35] as well as encapsulation of bacteriocin can increase its antibacterial activity against pathogens [36]. Thus, research on bacteriocins and AMPs generally will be crucial for further practical use, production, and their application as alternatives to antibiotics by themselves or in synergistic use with probiotics and bacteriophages.

\section{Bacteriophages}

Bacteriophages are bacterial viruses that act as natural predators of bacteria making them a specifically tailored weapon. Even though already at the beginning of the twentieth century, phages were known for their antibacterial properties, only after the emergence of widespread multi antibiotic-resistant strains, research and clinical trials of bacteriophages were undertaken again on a larger scale. Phage therapy relies on the natural mechanism of bacteria cell lysis at the site of infection. However current biotechnological advances fairly broadened the range of potential bacteriophage therapeutics by the usage of purified lytic proteins or engineered phages [37].

Production of bacteriophages has a long history, the bestknown phages are in the area of veterinary medicine, especially applicable to living farm animals [38]. In parallel, many clinical trials of phage therapy are now being assayed in humans [39]. They can be effective alone or increase low antibiotic concentration effectiveness, for example in the treatment of Staphylococcus aureus [40]. An interesting example of bacteriophage and bacteriocin cooperation is the successful control of $E$. coli both in vitro and in a mouse model by the receptor-binding domains of colicin A with an E. coli phage lysin [41]. Many promising results have been obtained in the last several years in defeating pathogens such as $S$. aureus [42], foodborne $E$. coli [43], and $S$. enterica ser. Typhimurium [44]. Interestingly, research on encapsulation of phages allowed to increase the effectiveness of oral therapy for both animals and humans mainly by decreasing gastrointestinal enzyme digestion [45, 46]. Another promising development is the genetic engineering of phages leading to the elimination of immunodominant epitopes and decreasing unwanted immune response during therapy, moreover, such manipulations can create precise bacteriophage variants against targeted pathogen [47, 48]. Veterinary phage vaccines are another interesting concept with encouraging results; however, this approach focuses rather on preventing bacterial infections than its treatment and is based on animal immune response system therefore it would not be further developed in this review [49]. The food industry is the second important area of phage application in particular the meat and raw animal production [50]. For example, a cocktail of specific bacteriophages effectively decreased the amount of $E$. coli bacteria in previously bacteria-inoculated meat samples [51]. Similarly, a mixture of bacteriophages isolated from chicken feces decreased the presence of $S$. enterica ser. Enteritidis on previously inoculated chicken skin [52] and S. enterica ser. Typhimurium on porcine skin [53]. Furthermore, bacteriophages can reduce S. aureus presence in milk [54]. Additionally, phages can be used also as an antibacterial treatment for plant diseases [55] and as an additive to food packaging [56]. 
To summarize bacteriophages have a considerable potential to be used as alternatives to antibiotic treatment. What is more, such therapy alone can be considered organic in regards to farm production [57]. Bacteriophages can act also as biosensors in recognizing dangerous VBNC foodborne pathogens, for example, they can distinguish viable and VBNC from dead Salmonella cells [58]. Unfortunately, administrative regulations for bacteriophages' use and knowledge about their possible side effects are still rather limited. It is also important to notice that bacteriophage resistance mechanisms can occur as a result of their usage [59]. However, strategies to combat the resistance problem are developed, for example, usage of bacteriophage cocktails (mixtures of more than one bacteriophage) decreases the effect of possible resistance mechanisms by targeting various kinds of mechanisms [60]. Moreover, reports regarding the spreading of foodborne bacterial resistance due to bacteriophages started to emerge causing questions about the security of their free use [61]. Although many successful examples of commercialization: Agriphage (Omnilytics Ltd.), Listex (Micreos, Ltd.), SalmFresh ${ }^{\circledR}$, ListShield ${ }^{\circledR}$, and EcoShield ${ }^{\circledR}$ (Intralytix Ltd.), show a foreseeable future for the phage therapy and its administrative regulations [62], provided by more research being carried out to facilitate public perception and safety profile [63].

\section{Plant-Derived Antimicrobial Compounds}

The natural antibacterial properties of plants have been known for centuries; however, only in the last decades, their power to control foodborne pathogens was scientifically confirmed, moreover, they are recognized as promising against antibiotic-resistant bacteria [64]. Plants are a natural and rich source of promising biologically active agents. During evolution, plants had to develop a variety of sophisticated strategies to survive continuous attacks of microorganisms in their environment. Because plants do not have cell-based immune responses, they had to create other methods of fighting bacteria. There are many functional compounds in plants such as polyphenols, phenols, micronutrients, phytochemicals, and essential oils. Those substances of plant origin are sometimes referred to in the literature as phytobiotics, especially in the case of animal nutrition [65]. These organic substances show a natural antioxidant potential as well as antimicrobial properties. It is estimated that there are over 30,000 active antimicrobial substances identified in plants [66]. The majority of essential oils obtained from popular herbs have an antimicrobial activity which is attributed to phenolic and terpenoid compounds and these lipophilic compounds can accumulate in bacterial membranes causing disturbances. Based on their chemical structure they can be classified into a few major groups including essential oils, alkaloids, phenolics

Table 2 General plant antimicrobials classification and its mechanisms

\begin{tabular}{|c|c|}
\hline Antimicrobial group & Mechanism \\
\hline Essential oils & $\begin{array}{l}\text { The mechanism of action on an antibiotic or other microorganisms cells is very complex, it involves, among others, } \\
\text { denaturation of membrane proteins, the disintegration of the cell membrane, and cell lysis of the microorganism. They } \\
\text { can also cause the inactivation of enzymes involved in membrane and wall synthesis, cellular and cell organelles, inter- } \\
\text { fere with cell membrane permeability and electron flow, inhibit the synthesis of DNA, RNA, uptake of proteins and } \\
\text { polysaccharides, participation in metabolic processes, and cell division. Essential oils are passed as substances with } \\
\text { high lipophilicity, easily penetrate the wall and cell membrane of microorganisms disrupting the integrity and impair- } \\
\text { ment activities essential for the survival of microbe. It is also believed that one of the possible mechanisms of action of } \\
\text { essential oils and plant extracts is inhibiting bacterial cell division }\end{array}$ \\
\hline Alkaloids & $\begin{array}{l}\text { The mode of action of several alkaloid classes such as isoquinoline and polyamine has been studied extensively fairly } \\
\text { recently. It has been reported that isoquinoline such as chelerythrine possesses two mechanisms in inhibiting the } \\
\text { growth of bacterial cells; through inhibiting the cellular division and nucleic acid synthesis. Isoquinoline inhibits cellu- } \\
\text { lar division by tampering with the FtsZ protein, a protein that is essential for the Z ring formation during cellular divi- } \\
\text { sion. Besides, the synthesis of nucleic acids is also inhibited as isoquinoline inhibits the action of type I topoisomer- } \\
\text { ases; this prevents the translation of antibiotic-resistant genes, increasing bacterial susceptibility toward antibiotics. } \\
\text { Polyamine, on the other hand, compromises the integrity and stability of the cell membrane, increasing the membrane } \\
\text { permeability via depolarization, leading to leakage of the cytoplasmic contents and later, cell death }\end{array}$ \\
\hline Phenolics & $\begin{array}{l}\text { Studies have shown that hydrolyzable tannins such as gallotannin are bioactive through the inhibition of glucosyltrans- } \\
\text { ferase which is involved in the formation of biopolymers such as DNA, RNA, and protein. Also, hydrolyzable tannins } \\
\text { disrupt the peptidoglycan cell wall and cytoplasmic membrane of a drug-resistant strain of Helicobacter pylori and } \\
\text { Candida albicans, leading to the leakage of cellular content and cell death }\end{array}$ \\
\hline Organosulfur & $\begin{array}{l}\text { The main mechanism involved in the antimicrobial effect is assumed to be the inhibition of thiol-containing enzymes } \\
\text { in microorganisms by the rapid reaction of thiosulfinates with thiol groups. Generally, organosulfur compounds show } \\
\text { their antimicrobial activity by altering the permeability of microbial cell walls and replacing intracellular and extracel- } \\
\text { lular materials with each other. For example, allicin causes quick and complete inhibition of RNA biosynthesis and } \\
\text { additionally a partial inhibition of DNA and protein synthesis }\end{array}$ \\
\hline
\end{tabular}


(listed in Table 2 together with their mechanism of action). The detailed mechanism involved is an important link contributing to the plant antimicrobial studies. Lately, there are innumerable scientific publications involving plant secondary metabolites and their antibacterial properties. Although only a small fraction of them include analysis of the action mode of antimicrobial plant metabolites for further assessment. Thus, leading to incomplete information on the mode of action which currently prevents substitution of antibiotics by plant secondary metabolites [67].

Chosen plants with activity against foodborne bacteria are shown in Table 3. Especially spices and herbs draw attention while thinking about antibacterial potential.
For example allicin, a compound isolated from garlic (Allium sativum), is a broad range growth inhibitor for Gramnegative and Gram-positive bacteria. It affects Escherichia, Salmonella [68], Streptococcus, Staphylococcus, Klebsiella, Proteus, and H. pylori [69]. All serogroups of E. coli, but especially enterohemorrhagic $E$. coli (serogroup O157) and enterotoxigenic $E$. coli (serogroup O8), were proven to be sensitive to the garlic extract [70]. Plant derivatives can also act as different antibiofilm factors [71]. For example, extracts of Cuminum cyminum [72] and Capparis spinosa [73] were proven to act as quorum-sensing inhibitors against Gram-negative bacterial pathogens. Capparis spinosa extract inhibited motility and interfered with the production of extracellular polymeric substances and biofilm in E. coli,

Table 3 Chosen plants and their activity against different foodborne pathogens

\begin{tabular}{|c|c|c|c|}
\hline Plant & Activity against & $\begin{array}{l}\text { The main group of antibacterial com- } \\
\text { pounds }\end{array}$ & References \\
\hline Garlic (Allium sativum) & $\begin{array}{l}\text { E. coli, } S \text {. aureus, L. monocytogenes } \\
\text { ATCC 7644, S. aureus ATCC 25923, E. } \\
\text { coli ATCC 25922, and } S . \text { enterica } \text { ser. } \\
\text { Enteritidis ATCC } 13076\end{array}$ & $\begin{array}{l}\text { Organosulfur compounds (allicin, diallyl } \\
\text { sulfides), } \\
\text { Phenolic compounds }\end{array}$ & {$[78,79]$} \\
\hline Horseradish (Armoracia rusticana) & $\begin{array}{l}\text { L. monocytogenes ATCC } 7644, S \text {. aureus } \\
\text { ATCC } 25923, \text { E. coli ATCC } 25922, S \text {. } \\
\text { enterica } \text { ser. Enteritidis ATCC } 13076\end{array}$ & $\begin{array}{l}\text { Organosulfur compounds (allyl isothio- } \\
\text { cyanate) }\end{array}$ & {$[80]$} \\
\hline Basil (Ocimum basilicum) & $\begin{array}{l}\text { S. aureus, E. coli, L. monocytogenes, and } \\
\text { S. enterica } \text { ser. Enteritidis }\end{array}$ & Essential oils & {$[81]$} \\
\hline Lemongrass (Cymbopogon citratus) & $\begin{array}{l}\text { S. aureus ATCC 25923, E. coli ATCC } \\
\text { 25922, L. monocytogenes ATCC 19117, } \\
\text { S. enterica ser. Enteritidis S64 }\end{array}$ & Essential oils & [82] \\
\hline Clove (Eugenia caryophillis) & $\begin{array}{l}\text { L. monocytogenes, } \text { S. enterica ser. Typh- } \\
\text { imurium, E. coli } \mathrm{O} 157: \mathrm{H} 7, \text { Sh. dysen- } \\
\text { teria, S. aureus, E. coli, and S. enterica } \\
\text { ser. Enteritidis }\end{array}$ & Essential oils & {$[83]$} \\
\hline Bay leaf (Laurus nobilis) & $\begin{array}{l}\text { L. monocytogenes ATCC } 19117, \text { S. enter- } \\
\text { ica ser. Enteritidis S64, E. coli O157:H7, } \\
\text { L. monocytogenes, S. enterica ser. Typh- } \\
\text { imurium, and S. aureus }\end{array}$ & Essential oils & [84] \\
\hline Onion (Allium cepa) & E. coli, S. aureus & Polyphenols, flavonoids, essential oils & {$[85]$} \\
\hline Oregano (Origanum glandulosum) & $\begin{array}{l}\text { E. coli, Lmonocytogenes, S. enterica } \\
\text { ser. Typhimurium, E. coli } \mathrm{O} 157: \mathrm{H} 7, \text { Sh. } \\
\text { dysenterie and } S \text {. aureus }\end{array}$ & Essential oils & {$[86]$} \\
\hline Peppermint (Mentha piperita) & S. enterica ser. Enteritidis & Essential oils & [87] \\
\hline Black Pepper (Piper nigrum) & S. enterica ser. Enteritidis & Flavonoids, essential oils & {$[88]$} \\
\hline Rosemary (Rosmarinus officinalis) & L. monocytogenes, and S. aureus & Essential oils & [89] \\
\hline Sage (Salvia officinalis) & $\begin{array}{l}\text { S. enterica ser. Enteritidis, L. monocy- } \\
\text { togenes, S. aureus }\end{array}$ & Essential oils & {$[90]$} \\
\hline Spanish Lavender (Lavandula stoechas L.) & $\begin{array}{l}\text { E. coli } \mathrm{O} 157: \mathrm{H} 7, \text { L. monocytogenes, } S \text {. } \\
\text { enterica ser. Typhimurium; }\end{array}$ & Essential oils & [91] \\
\hline Thyme (Thymus vulgaris) & $\begin{array}{l}\text { E. coli, } S \text {. enterica } \text { ser. Enteritidis, } L . \\
\text { monocytogenes, } S \text {. enterica } \text { ser. Typh- } \\
\text { imurium, E. coli } \mathrm{O} 157: \mathrm{H} 7, \text { Sh. dysente- } \\
\text { ria, Bacillus cereus, and } S . \text { aureus }\end{array}$ & Essential oils & {$[92]$} \\
\hline Ginger (Zingiber officinale) & $\begin{array}{l}\text { L. monocytogenes, } S \text {. enterica } \text { ser. } \\
\text { Typhimurium, E. coli } \mathrm{O} 157: \mathrm{H} 7, \text { Sh. } \\
\text { dysenterie, E. coli, S. aureus }\end{array}$ & $\begin{array}{l}\text { Phenolic compounds, flavonoids (gingerol, } \\
\text { shogaol, and zingerone) }\end{array}$ & {$[66]$} \\
\hline
\end{tabular}


Proteus mirabilis, Serratia marcescens. A growing body of literature has examined citrus plant extracts as rich in various flavonoids, including apigenin, kaempferol, quercetin, and naringenin which can also inhibit biofilm formation in E. coli O157:H7 [74] or repress Salmonella pathogenicity [75]. Lately, one of the molecules extracted from the tree Diospyros dendo, known as ursolic acid, gained much attention due to the successful inhibition of $E$. coli bacterial biofilms in five different $E$. coli hosts (K-12, JM109, C600, EJ500, and JCB495) [76]. The addition of ursolic acid to destabilize biofilms is a promising approach since it is active in low concentrations, this plant-derived compound can be added as a complementary factor to increase the susceptibility of bacterial cells for other antibacterials especially where bacteria are prone to form difficult to target biofilm structures, e.g., in animal production pipelines. Moreover, ursolic acid is non-toxic to hepatocytes. What is important currently there is no evidence that plant extracts could induce a VBNC state in bacteria [77].

Phytochemicals isolated from Chinese and Indian herbs function as immunostimulants, for example in aquacultures [93]. Studies showed that plant compounds and their derivatives could cooperate with probiotics, both due to their negative impact on pathogens and positive impact on gut microflora [94]. However, plant extracts differ from one another as far as the concentrations needed to affect certain bacteria are concerned. It is important to establish common concentrations of plant extracts that have a minimum inhibitory or a minimum bactericidal effect. This could increase the usage of plant extracts as antimicrobial additives in animal feed. However, there are still a few questions that should be examined such as: will animals consume the feed with plant extracts or if there are any side effects of such a diet. Genetically modified plants seem to be an interesting possibility, recombinant DNA technology allows producing food or animal feed that already contains active substances. Minimal processing and avoiding extensive purification costs could provide inexpensive and widely available products [95].

\section{Probiotics and Prebiotics}

Prebiotics are substances that contribute to the growth of microorganisms that are advantageous for their host. The use of probiotics as agents against foodborne pathogens is becoming increasingly popular. The category of probiotic bacteria is wide; however, main groups can be distinguished such as Lactobacillus, Bifidobacteriaceae, and Streptococcus. Those microorganisms act both as a prevention and control of pathogenic bacteria, supplied to an organism get involved in physiological and immunological processes. In many cases, a pathogen infection is strictly connected to the host's gut state. To open the door for normal and balanced intestinal colonization, the administration of mixed probiotics and commensal bacteria is recommended. Such an approach and was proven to facilitate the gut microflora function by filling down possible niches for pathogenic bacteria. Secondly, they stimulate the immune system and support defense responses to pathogenic bacteria. Mechanisms of probiotics action are presented in Table 4. Besides that, the vast majority of probiotics also produce bacteriocins.

In humans, evidence shows that probiotics can decrease infections and antibiotic-associated diarrhea [96]. Moreover, some strains of probiotic bacteria showed also antimicrobial activity against foodborne pathogens [97]. However, using this technique alone does not seem to lead to the full elimination of pathogenic bacterial infections. Nevertheless, a probiotic approach can reduce cross-contamination and dissemination of infections [98].

In agricultural production, probiotics are already used as a feed additive in aquacultures [99], in chicken [100], pigs

Table 4 Major mechanisms of probiotics action

\begin{tabular}{ll}
\hline Major mechanisms of probiotic action & \\
\hline Common to many types of probiotics & - Protection against colonization \\
& - Production of short-chain fatty acids; effect on intestinal passage \\
& - Microbiota stabilization/normalization \\
& - Acceleration of enterocyte exchange \\
& - Competition with pathogens \\
& - Production of B group vitamins (B1, B2, B6, B8, B12), PP-niacin, folic acid, \\
Common for individual species & stimulate the formation of organic acids and amino acids \\
& - Production of lactic acid (decreases absorption of toxic substances into the \\
& - Dlood) \\
& - Stabilization of the intestinal barrier \\
& - Bile salt metabolism \\
& - Enzymatic activity and carcinogen neutralization \\
& - Immune response modulation \\
Rare mechanisms (specific to individual strains) & - Production of specific bioactive substances; endocrine and neurogenic effects
\end{tabular}


[101], and cattle [102]. Research results on probiotic usage in livestock production, show positive growth response in animals and decreased E. coli and Clostridium amount, bacteria responsible for diarrheal diseases [103]. Moreover, current studies suggest that especially combination of probiotics and antimicrobial plant extracts is more effective in preventing foodborne infections than when they are applied separately [104]. Probiotics can fight the biofilm formation of pathogenic E. coli [105]. However, their effectivity of blocking pathogenic bacterial and fungal biofilms creation is based on a probiotic combination [106]. To properly select functional probiotics there can be distinguished major characteristics for the safety and technological usefulness (Table 5). A growing body of literature has examined probiotics being used in animal feed, usually in combination with other compounds, for instance, calves feed with multi-strain Lactobacillus probiotic with a combination of phytobiotics with rosmarinic acid improved their health status (reduced occurrence of diarrhea due to reduced amount of Cryptosporidium, and Giardia duodenalis), starter intake, growth performance, and metabolic status [107].

\section{Conclusion}

The discovery and development of alternatives to antibiotics are currently critically important. The perfect antimicrobial agents should have a possibly narrow spectrum against pathogens and should not cause significant side effects (e.g., diarrhea, colitis, shortage of commensal bacteria). In
Table 6, biological antimicrobial agents described in the article have been compared with traditional antibiotics in regards to their safety and toxicity profile. Combining a few non-antibiotic approaches can bring positive results in pathogen prevention. Choosing the right method is a multifactor decision based on efficacy, economics, safety for human and animal health, availability of the treatment, and finally the probability of inducing bacteria resistance.

Developing methods as effective as current antibiotic treatments can bring positive changes in countries where those drugs are still approved and overused in livestock production. The majority of the proposed non-antibiotic methods were designed for both humans and animals. Farm production of animals is the first step of the food industry and it is highly important for the safety of the final product and human health. What is more, antibiotic use in the agricultural environment should be reduced as soon as possible to stop the development of resistance by bacteria and to keep the antibiotic effective at least against human infections. Otherwise, in the foreseeable future, we will have to face a dramatic shortage of effective antimicrobial agents for preventing and treatment of bacterial diseases.

While developing novel, more specific methods for the prevention of diseases, it seems highly important to test the pathogens for possible resistance mechanisms [108]. Another emerging challenge in food antimicrobials is inducing a "viable but nonculturable" (VBNC) state by the popular non-biological food sanitizing methods such as temperature, antibiotics, oxygen availability, and others [109]. Bacteria entering the VBNC state represent
Table 5 Chosen criteria for the selection of probiotic strains for human and animal use

\begin{tabular}{ll}
\hline Criteria & Required properties \\
\hline Health safety & Natural origin \\
- Isolated from the digestive tract of healthy individuals/animals \\
- Should show a safe use history \\
- Lack of bile acid cleaving skills \\
- No side effects \\
- Lack of antibiotic resistance genes that are located on unstable elements \\
- Competitiveness to the microflora that inhabits the intestinal ecosystem \\
- Survivability, metabolic activity, and growth at destination \\
- Resistant to bile salts \\
- Resistance to the acidic environment of gastric juice \\
- Competitiveness for closely related species \\
- Antagonist activity to foodborne pathogens such as $H$. pylori, Salmo- \\
nella sp., L. monocytogenes, and $C$. difficile \\
- Resistance to bacteriocins and acids produced by the endogenous \\
microflora that inhabits the intestinal ecosystem \\
- Adhesion and the ability to colonize specific places in the body \\
- Easy to produce large amounts of biomass \\
- Viability and stability of desirable probiotic bacteria traits during prod- \\
- uct preparation and distribution \\
- High bacterial storage survival in finished food products \\
- Guaranteeing the desired sensory properties of finished food products \\
- Genetic stability \\
- Resistance to bacteriophages
\end{tabular}


Table 6 Comparison of antibiotics versus biological alternatives against bacterial foodborne pathogens

\begin{tabular}{|c|c|c|c|c|c|}
\hline Characteristic & Antibiotics & Bacteriocins & Bacteriophages & Plant antimicrobials & Probiotics \\
\hline Synthesis & $\begin{array}{l}\text { Enzymes (secondary } \\
\text { metabolite) }\end{array}$ & $\begin{array}{l}\text { Ribosomal (primary } \\
\text { metabolite) }\end{array}$ & Bacterial & $\begin{array}{l}\text { Secondary metabo- } \\
\text { lites }\end{array}$ & Bacterial \\
\hline Bioengineering & Not amendable & Highly amendable & Amendable & Not amendable & Amendable \\
\hline Spectrum of activity & Mainly broad & $\begin{array}{l}\text { Narrow (confined } \\
\text { to closely related } \\
\text { species) }\end{array}$ & Narrow & Broad & Medium \\
\hline Biocompatibility & Toxic & $\begin{array}{l}\text { Only toxic at high } \\
\text { concentrations }\end{array}$ & Non-toxic & Non-toxic & Non-toxic \\
\hline $\begin{array}{l}\text { Working concentra- } \\
\text { tions (MIC) }\end{array}$ & $\begin{array}{l}\text { Higher (usually in the } \\
\text { micromolar range) }\end{array}$ & $\begin{array}{l}\text { Lower (Often in the } \\
\text { pico-nanomolar } \\
\text { range) }\end{array}$ & Lower & $\begin{array}{l}\text { Higher (usually in the } \\
\text { micromolar range) }\end{array}$ & $\begin{array}{l}\text { Higher (usually in the } \\
\text { micromolar range) }\end{array}$ \\
\hline $\begin{array}{l}\text { Chemical and thermal } \\
\text { stability }\end{array}$ & $\begin{array}{l}\text { Tolerate a narrow } \\
\text { range of } \mathrm{PH} \text { and } \\
\text { temperature }\end{array}$ & $\begin{array}{l}\text { Tolerate a wide range } \\
\text { of } \mathrm{pH} \text { and tempera- } \\
\text { ture }\end{array}$ & $\begin{array}{l}\text { Tolerate a medium } \\
\text { range of } \mathrm{pH} \text { and } \\
\text { temperature }\end{array}$ & $\begin{array}{l}\text { Tolerate a wide range } \\
\text { of } \mathrm{pH} \text { and tempera- } \\
\text { ture }\end{array}$ & $\begin{array}{l}\text { Tolerate a narrow } \\
\text { range of } \mathrm{PH} \text { and } \\
\text { temperature }\end{array}$ \\
\hline Adverse effects & Many & None identified & None identified & $\begin{array}{l}\text { Few (at high concen- } \\
\text { trations) }\end{array}$ & $\begin{array}{l}\text { Few (at high concen- } \\
\text { trations) }\end{array}$ \\
\hline $\begin{array}{l}\text { Diversity (i.e., in } \\
\text { terms of size, micro- } \\
\text { bial target, mode of } \\
\text { action, etc.) }\end{array}$ & Narrow & Broad & Broad & Broad & Medium \\
\hline Biodegradable & Persistent & $\begin{array}{l}\text { Completely metabo- } \\
\text { lized in the human } \\
\text { body }\end{array}$ & Biodegradable & $\begin{array}{l}\text { Completely biode- } \\
\text { gradable }\end{array}$ & $\begin{array}{l}\text { Completely biodegrad- } \\
\text { able }\end{array}$ \\
\hline Antibiofilm properties & Resistance & Strong & Medium & Medium & Strong \\
\hline Cost & Low & High & Medium & Low & Medium \\
\hline Purification & Possible, high yield & $\begin{array}{l}\text { Complicated, low } \\
\text { yield }\end{array}$ & $\begin{array}{l}\text { Complicated, high } \\
\text { yield }\end{array}$ & Easy, high yield & Doesn't apply \\
\hline Specificity & Specific & Specific & Specific & Non-specific & Medium specific \\
\hline Selectivity & Selective & Non-selective & Non-selective & Non-selective & Non-selective \\
\hline Bioavailability & Good & Size-dependent & Class dependent & Class dependent & Good \\
\hline Oral bioavailability & Good & Poor & Medium & Good & Good \\
\hline Solubility & Variable (low to high) & Low & Low & Variable & Low \\
\hline Metabolic stability & $\begin{array}{l}\text { Slow-fast biotransfor- } \\
\text { mation }\end{array}$ & $\begin{array}{l}\text { Low (Fast biotransfor- } \\
\text { mation) }\end{array}$ & Medium stable & Medium stable & Medium stable \\
\hline Resistance & High occurrence & Possible occurrence & Possible occurrence & No resistance & No resistance \\
\hline
\end{tabular}

a serious risk to human health and can induce possible foodborne illnesses. Traditional culture-based methods of foodborne bacteria detection suggest that the tested sample is bacteria-free when in fact pathogens can be present in the VBNC state. Many biological antimicrobial solutions can act as a supplementary treatment to lower the risk of VBNC state in bacteria or inhibit biofilm formation. While testing any new antimicrobial it is important to remember that beyond the CFU method additional methods should be used to check the presence of VBNC state and biofilm formation of bacteria. Furthermore, proper education of individuals using antimicrobials (such as doctors, farmers, food engineers, etc.) is still needed to slow down the processes of gaining resistance by pathogenic bacteria. Also, national and private scientific funding programs should prioritize projects aiming to find efficient alternative strategies for antibiotics. While many countries start to tighten antibiotic regulations, soon it will be necessary to implement alternative substances on a large scale. Due to that, it is extremely significant, especially for the food and breeding industry, to find new, safe, and efficient nonantibiotic solutions against bacterial pathogens.

Author Contribution EŁ conceived the original idea, designed the paper, and wrote the manuscript. TS was involved in planning and supervised the work.

\section{Declarations}

Conflicts of interest The authors declare no conflict of interest. 
Open Access This article is licensed under a Creative Commons Attribution 4.0 International License, which permits use, sharing, adaptation, distribution and reproduction in any medium or format, as long as you give appropriate credit to the original author(s) and the source, provide a link to the Creative Commons licence, and indicate if changes were made. The images or other third party material in this article are included in the article's Creative Commons licence, unless indicated otherwise in a credit line to the material. If material is not included in the article's Creative Commons licence and your intended use is not permitted by statutory regulation or exceeds the permitted use, you will need to obtain permission directly from the copyright holder. To view a copy of this licence, visit http://creativecommons.org/licenses/by/4.0/.

\section{References}

1. World Health Organization (2015) WHO estimates of the global burden of foodborne diseases: foodborne disease burden epidemiology reference group 2007-2015. WHO, Geneva

2. Mclinden T, Sargeant JM, Thomas MK, Papadopoulos A, Fazil A (2014) Component costs of foodborne illness: a scoping review. BMC Public Health 14:509

3. Agunos A, Arsenault RK, Avery BP, Deckert AE, Gow SP, Janecko N, McEwen SA (2018) Changes in antimicrobial resistance levels among Escherichia coli, Salmonella, and Campylobacter in Ontario broiler chickens between 2003 and 2015. Can J Vet Res 82(3):163-177

4. Hashem F, Parveen S (2016) Salmonella and Campylobacter: Antimicrobial resistance and bacteriophage control in poultry. Food Microbiol 53:104-109

5. Rohr JR, Barrett CB, Civitello DJ, Craft ME, Delius B, DeLeo GA, Tilman D (2019) Emerging human infectious diseases and the links to global food production. Nature sustainability 2(6):445-456

6. Jayalakshmi K, Paramasivam M, Sasikala M, Tamilam TV, Sumithra A (2017) Review on antibiotic residues in animal products and its impact on environments and human health. J Entomol Zool Stud 5(3):1446-1451

7. Xie WY, Shen Q, Zhao FJ (2018) Antibiotics and antibiotic resistance from animal manures to soil: a review. Eur J Soil Sci 69(1):181-195

8. Centers for Disease Control and Prevention (2019) Antibiotic resistance threats in the United States. https://www.cdc.gov/ drugresistance/pdf/threats-report/2019-ar-threats-report-508. pdf. Accessed 13 Dec 2020.

9. Årdal C, Balasegaram M, Laxminarayan R, McAdams D, Outterson K, Rex JH, Sumpradit N (2020) Antibiotic development-economic, regulatory and societal challenges. Nat Rev Microbiol 18(5):267-274

10. Ganguly NK, Arora NK, Chandy SJ, Fairoze MN, Gill JP, Gupta U, Laxminarayan R (2011) Global antibiotic resistance partnership (GARP): India Working Group. Rationalizing antibiotic use to limit antibiotic resistance in India. Indian J Med Res 134(3):281-294

11. Chokshi A, Sifri Z, Cennimo D, Horng H (2019) Global contributors to antibiotic resistance. J Glob Infect Dis 11(1):36

12. Roman S, Sánchez-Siles LM, Siegrist M (2017) The importance of food naturalness for consumers: results of a systematic review. Trends Food Sci Technol 67:44-57

13. Hu B, Pan Y, Li Z, Yuan W, Deng L (2019) EmPis-1L, an effective antimicrobial peptide against the antibiotic-resistant VBNC state cells of pathogenic bacteria. Probiotics Antimicrob Proteins 11(2):667-675

14. Yasir M, Willcox MDP, Dutta D (2018) Action of antimicrobial peptides against bacterial biofilms. Materials 11(12):2468
15. Andersson E, Rydengård V, Sonesson A, Mörgelin M, Björck L, Schmidtchen A (2004) Antimicrobial activities of heparinbinding peptides. Eur J Biochem 271(6):1219-1226

16. Cheng C, Arritt F, Stevenson C (2015) Controlling Listeria monocytogenes in cold smoked salmon with the antimicrobial peptide salmine. J Food Sci 80(6):M1314-M1318

17. Wu J, Hu Y, Du C, Piao J, Yang L, Yang X (2016) The effect of recombinant human lactoferrin from the milk of transgenic cows on Salmonella enterica serovar Typhimurium infection in mice. Food Funct 7(1):308-314

18. Potter R, Hansen LT, Gill TA (2005) Inhibition of foodborne bacteria by native and modified protamine: importance of electrostatic interactions. Int J Food Microbiol 103(1):23-34

19. Lahov E, Regelson W (1996) Antibacterial and immunostimulating casein-derived substances from milk: casecidin, isracidin peptides. Food Chem Toxicol 34(1):131-145

20. Påhlman LI, Mörgelin M, Kasetty G, Olin AI, Schmidtchen A, Herwald H (2013) Antimicrobial activity of fibrinogen and fibrinogen-derived peptides-a novel link between coagulation and innate immunity. Thromb Haemost 109(5):930-939

21. Burrowes OJ, Hadjicharalambous C, Diamond G, Lee TC (2004) Evaluation of antimicrobial spectrum and cytotoxic activity of pleurocidin for food applications. J Food Sci 69(3):M66-M71

22. Wu WH, Di R, Matthews KR (2013) Activity of the plant-derived peptide Ib-AMP1 and the control of enteric foodborne pathogens. Food Control 33(1):142-147

23. Conte M, Aliberti F, Fucci L, Piscopo M (2007) Antimicrobial activity of various cationic molecules on foodborne pathogens. World J Microbiol Biotechnol 23(12):1679-1683

24. Chikindas ML, Weeks R, Drider D, Chistyakov VA, Dicks LM (2018) Functions and emerging applications of bacteriocins. Curr Opin Biotechnol 49:23-28

25. Khan I, Oh DH (2016) Integration of nisin into nanoparticles for application in foods. Innov Food Sci Emerg Technol 34:376-384

26. Walsh MC, Gardiner GE, Hart OM, Lawlor PG, Daly M, Lynch B, Fitzgerald GF (2008) Predominance of a bacteriocin-producing Lactobacillus salivarius component of a five-strain probiotic in the porcine ileum and effects on host immune phenotype. FEMS Microbiol Ecol 64(2):317-327

27. Millette M, Cornut G, Dupont C, Shareck F, Archambault D, Lacroix M (2008) Capacity of human nisin-and pediocin-producing lactic acid bacteria to reduce intestinal colonization by vancomycin-resistant Enterococci. J Appl Environ Microbiol 74(7):1997-2003

28. Lopez FE, Vincent PA, Zenoff AM, Salomón RA, Farías RN (2007) Efficacy of microcin J25 in biomatrices and in a mouse model of Salmonella infection. J Antimicrob Chemother 59(4):676-680

29. Mathur H, Field D, Rea MC, Cotter PD, Hill C, Ross RP (2018) Fighting biofilms with lantibiotics and other groups of bacteriocins. NPJ Biofilms Microbiomes 4(1):1-13

30. Kim NN, Kim WJ, Kang SS (2019) Anti-biofilm effect of crude bacteriocin derived from Lactobacillus brevis DF01 on Escherichia coli and Salmonella Typhimurium. Food Control 98:274-280

31. Perales-Adán J, Rubiño S, Martínez-Bueno M, Valdivia E, Montalbán-López M, Cebrián R, Maqueda M (2018) LAB bacteriocins controlling the food isolated (drug-resistant) staphylococci. Front Microbiol 9:1143

32. Baños A, García-López JD, Núñez C, Martínez-Bueno M, Maqueda M, Valdivia E (2016) Biocontrol of Listeria monocytogenes in fish by enterocin AS-48 and Listeria lytic bacteriophage P100. LWT Food Sci Technol 66:672-677 
33. Yang SC, Lin CH, Sung CT, Fang JY (2014) Antibacterial activities of bacteriocins: application in foods and pharmaceuticals. Front Microbiol 5:241

34. Łojewska E, Sakowicz T, Kowalczyk A, Konieczka M, Grzegorczyk J, Sitarek P, Kowalczyk T (2020) Production of recombinant colicin M in Nicotiana tabacum plants and its antimicrobial activity. Plant Biotechnol Rep 14:33-43

35. Chatzidaki MD, Papadimitriou K, Alexandraki V, Balkiza F, Georgalaki M, Papadimitriou V, Xenakis A (2018) Reverse micelles as nanocarriers of nisin against foodborne pathogens. Food Chem 255:97-103

36. Cantor S, Vargas L, Rojas A, Yarce CJ, Salamanca CH, OñateGarzón J (2019) Evaluation of the antimicrobial activity of cationic peptides loaded in surface-modified nanoliposomes against foodborne bacteria. Int J Mol Sci 20(3):680

37. Yosef I, Manor M, Kiro R, Qimron U (2015) Temperate and lytic bacteriophages programmed to sensitize and kill antibiotic-resistant bacteria. Proc Natl Acad Sci USA 112(23):7267-7272

38. Squires RA (2018) Bacteriophage therapy for management of bacterial infections in veterinary practice: what was once old is new again. $\mathrm{N} Z$ Vet $\mathrm{J}$ 66(5):229-235

39. Gerstmans H, Criel B, Briers Y (2017) Synthetic biology of modular endolysins. Biotechnol Adv 36:624-640. https://doi. org/10.1016/j.biotechadv.2017.12.009

40. Dickey J, Perrot V (2019) Adjunct phage treatment enhances the effectiveness of low antibiotic concentration against Staphylococcus aureus biofilms in vitro. PLoS ONE 14(1):e0209390

41. Yan G, Liu J, Ma Q, Zhu R, Guo Z, Gao C et al (2017) The $\mathrm{N}$-terminal and central domain of colicin A enables phage lysin to lyse Escherichia coli extracellularly. Antonie Van Leeuwenhoek 110(12):1627-1635

42. Ma Y, Pacan J, Wang Q, Sabour P, Huang X, Xu Y (2012) Enhanced alginate microspheres as means of oral delivery of bacteriophage for reducing Staphylococcus aureus intestinal carriage. Food Hydrocoll 26(2):434-440

43. Weiss M, Denou E, Bruttin A, Serra-Moreno R, Dillmann M-L, Brüssow H (2009) In vivo replication of T4 and T7 bacteriophages in germ-free mice colonized with Escherichia coli. Virology 393(1):16-23

44. Wong C, Sieo C, Tan W, Abdullah N, Hair-Bejo M, Abu J, Ho Y (2014) Evaluation of a lytic bacteriophage, $\Phi$ st1, for biocontrol of Salmonella enterica serovar Typhimurium in chickens. Int J Food Microbiol 172(2014):92-101

45. Otero J, García-Rodríguez A, Cano-Sarabia M, Maspoch D, Marcos R, Cortés P, Llagostera M (2019) Biodistribution of liposome-encapsulated bacteriophages and their transcytosis during oral phage therapy. Front Microbiol 10:689

46. Jamaledin R, Sartorius R, Di Natale C, Vecchione R, De Berardinis P, Netti PA (2020) Recombinant filamentous bacteriophages encapsulated in biodegradable polymeric microparticles for stimulation of innate and adaptive immune responses. Microorganisms 8(5):650

47. Chen Y, Batra H, Dong J, Chen C, Rao VB, Tao P (2019) Genetic engineering of bacteriophages against infectious diseases. Front Microbiol 10:954

48. Pizarro-Bauerle J, Ando H (2020) Engineered bacteriophages for practical applications. Biol Pharm Bull 43(2):240-249

49. Qureshi S, Saxena HM (2017) A novel phage based marker vaccine and DIVA assay for hemorrhagic septicemia in bovines. Pak Vet J 37:95-99

50. Gutiérrez D, Rodríguez-Rubio L, Martínez B, Rodríguez A, García P (2016) Bacteriophages as weapons against bacterial biofilms in the food industry. Front Microbiol. https://doi.org/ 10.3389/fmicb.2016.00825
51. Liu H, Niu Y, Meng R, Wang J, Li J, Johnson R, McAllister T, Stanford K (2015) Control of Escherichia coli O157 on beef at 37,22 and $4{ }^{\circ} \mathrm{C}$ by T5-, T1-, T4- and O1-like bacteriophages. Food Microbiol 51(2015):69-73

52. Moreira HH, Santos MR, Meireles GD, Vanetti C, de Oliveira PC (2013) Use of bacteriophages to reduce Salmonella in chicken skin in comparison with chemical agents. Food Res Int 52(1):75-81

53. Hooton S, Atterbury R, Connerton I (2011) Application of a bacteriophage cocktail to reduce Salmonella typhimurium U288 contamination on pig skin. Int J Food Microbiol 151(2):157-163

54. García P, Madera C, Martínez B, Rodríguez A, Evaristo SJ (2009) Microbial population dynamics in presence of lactococcal bacteriophage during ripening of traditional raw milk Romanian cheese. J Dairy Sci 92(7):3019-3026

55. Buttimer C, McAuliffe O, Ross RP, Hill C, O’Mahony J, Coffey A (2017) Bacteriophages and bacterial plant diseases. Front Microbiol 8:34

56. Chai Z, Wang J, Tao S, Mou H (2014) Application of bacteriophage-borne enzyme combined with chlorine dioxide on controlling bacterial biofilm. LWT Food Sci Technol 59:1159-1165

57. Easwaran M, Ahn J (2019) Application of bacteriophages in organic farm animal production. Safety and practice for organic food. Academic Press, New York, pp 365-375

58. Fernandes E, Martins VC, Nóbrega C, Carvalho CM, Cardoso FA, Cardoso S, Azeredo J (2014) A bacteriophage detection tool for viability assessment of Salmonella cells. Biosens Bioelectron $52: 239-246$

59. Baltz RH (2018) Bacteriophage-resistant industrial fermentation strains: from the cradle to CRISPR/Cas9. J Ind Microbiol Biotechnol 45(11):1003-1006

60. Merabishvili M, Pirnay JP, De Vos D (2018) Guidelines to compose an ideal bacteriophage cocktail. Bacteriophage therapy. Humana Press, New York, pp 99-110

61. Colavecchio A, Cadieux B, Lo A, Goodridge LD (2017) Bacteriophages contribute to the spread of antibiotic resistance genes among foodborne pathogens of the Enterobacteriaceae familya review. Front Microbiol 8:1108

62. Fernández L, Gutiérrez D, Rodríguez A, García P (2018) Application of bacteriophages in the agro-food sector: a long way towards approval. Front Cell Infect Microbiol 8:296

63. Cooper IR (2016) A review of current methods using bacteriophages in live animals, food and animal products intended for human consumption. J Microbiol Meth 130:38-47

64. Ng WJ, Shit CS, Ee KY, Chai TT (2021) Plant natural products for mitigation of antibiotic resistance. Sustain Agric Rev 49:57-91

65. Bagno OA, Prokhorov ON, Shevchenko SA, Shevchenko AI, Dyadichkina TV (2018) Use of phytobiotics in farm animal feeding. Sel'skokhozyaistvennaya Biol 53:687-697

66. Tajkarimi MM, Ibrahim SA, Cliver DO (2010) Antimicrobial herb and spice compounds in food. Food Control 21:1199-1218

67. Khameneh B, Iranshahy M, Soheili V, Bazzaz BSF (2019) Review on plant antimicrobials: a mechanistic viewpoint. Antimicrob Resist Infect Control 8(1):118

68. Belguith H, Kthiri F, Ben Ammar A, Jaafoura H, Ben Hamida J, Landoulsi A (2009) Morphological and biochemical changes of Salmonella hadar exposed to aqueous garlic extract. Int J Morphol 27:705-713

69. Ankri S, Mirelman D (1999) Antimicrobial properties of allicin from garlic. Microbes Infect 1(2):125-129

70. Indu MN, Hatha AAM, Abirosh C, Harsha U, Vivekanandan G (2006) Antimicrobial activity of some of the south-Indian spices against serotypes of Escherichia coli, Salmonella, Listeria 
monocytogenes and Aeromonas hydrophila. Braz J Microbiol 37(2):153-158

71. Villa F, Cappitelli F (2013) Plant-derived bioactive compounds at sub-lethal concentrations: towards smart biocide-free antibiofilm strategies. Phytochem Rev 12(1):245-254

72. Packiavathy IASV, Agilandeswari P, Musthafa KS, Pandian SK, Ravi AV (2012) Antibiofilm and quorum sensing inhibitory potential of Cuminum cyminum and its secondary metabolite methyl eugenol against Gram- negative bacterial pathogens. Food Res Int 45(1):85-92

73. Abraham SVPI, Palani A, Ramaswamy BR, Shunmugiah KP, Arumugam VR (2011) Antiquorum sensing and antibiofilm potential of Capparis spinosa. Arch Med Res 42(8):658-668

74. Vikram A, Jayaprakasha GK, Jesudhasan PR, Pillai SD, Patil BS (2010) Suppression of bacterial cell-cell signalling, biofilm formation and type III secretion system by citrus flavonoids. J Appl Microbiol 109(2):515-527

75. Vikram A, Jesudhasan PR, Jayaprakasha GK, Pillai SD, Jayaraman A, Patil BS (2011) Citrus flavonoid represses Salmonella pathogenicity island 1 and motility in $S$. Typhimurium LT2. Int J Food Microbiol 145(1):28-36

76. Ren D, Zuo R, Barrios AFG, Bedzyk LA, Eldridge GR, Pasmore ME, Wood TK (2005) Differential gene expression for investigation of Escherichia coli biofilm inhibition by plant extract ursolic acid. Appl Environ Microbiol 71(7):4022-4034

77. Rao AP (2017) Plant antimicrobials: inactivation of foodborne pathogens or induction into the VBNC state and their effects on the sensory properties of organic romaine lettuce. Master Thesis, University of Arizona

78. Abad P, Lara FJ, Arroyo-Manzanares N, Baños A, Guillamón E, García-Campaña AM (2015) High-performance liquid chromatography method for the monitoring of the allium derivative propyl propane thiosulfonate used as natural additive in animal feed. Food Anal Method 8(4):916-921

79. Peinado MJ, Ruiz R, Echávarri A, Rubio LA (2012) Garlic derivative propyl propane thiosulfonate is effective against broiler enteropathogens in vivo. Poult Sci 91(9):2148-2157

80. Nedorostova L, Kloucek P, Kokoska L, Stolcova M, Pulkrabek J (2009) Antimicrobial properties of selected essential oils in vapour phase against foodborne bacteria. Food Control 20(2):157-160

81. Tirawat D, Phongpaichit S, Benjakul S, Sumpavapol P (2016) Microbial load reduction of sweet basil using acidic electrolyzed water and lactic acid in combination with mild heat. Food Control 64:29-36

82. Zakuan Z, Chia CT, Rukayadi Y (2016) In vitro antimicrobial activity of Cymbopogon citratus (lemongrass) extracts against selected foodborne pathogens. Int Food Res J 23(3):1262-1267

83. Barbosa LN, Rall VLM, Fernandes AAH, Ushimaru PI, da Silva PI, Fernandes A Jr (2009) Essential oils against foodborne pathogens and spoilage bacteria in minced meat. Foodborne Pathog Dis 6(6):725-728

84. Millezi AF, Caixeta DS, Rossoni DF, Cardoso MDG, Piccoli RH (2012) In vitro antimicrobial properties of plant essential oils Thymus vulgaris, Cymbopogon citratus and Laurus nobilis against five important foodborne pathogens. Food Sci Technol (Campinas) 32(1):167-172

85. Bakht J, Khan S, Shafi M (2014) In vitro antimicrobial activity of Allium cepa (dry bulbs) against Gram-positive and Gram-negative bacteria and fungi. Pak J Pharm Sci 27(1):139-145

86. Bhargava K, Conti DS, da Rocha SR, Zhang Y (2015) Application of an oregano oil nanoemulsion to the control of foodborne bacteria on fresh lettuce. Food Microbiol 47:69-73

87. Jianu C, Golet I, Misca C, Jianu AM, Pop G, Gruia AT (2016) Antimicrobial properties and chemical composition of essential oils isolated from six medicinal plants grown in Romania against foodborne pathogens. Rev Chim 67(6):1056-1061
88. Al-Turki AI (2007) Antibacterial effect of thyme, peppermint, sage, black pepper and garlic hydrosols against Bacillus subtilis and Salmonella Enteritidis. J Food Agric Environ 5(2):92

89. Gutierrez J, Rodriguez G, Barry-Ryan C, Bourke P (2008) Efficacy of plant essential oils against foodborne pathogens and spoilage bacteria associated with ready-to-eat vegetables: antimicrobial and sensory screening. J Food Prot 71(9):1846-1854

90. Moghimi R, Aliahmadi A, McClements DJ, Rafati H (2016) Investigations of the effectiveness of nanoemulsions from sage oil as antibacterial agents on some food borne pathogens. LWT Food Sci Technol 71:69-76

91. Dadalioğlu I, Evrendilek GA (2004) Chemical compositions and antibacterial effects of essential oils of Turkish oregano (Origanum minutiflorum), bay laurel (Laurus nobilis), Spanish lavender (Lavandula stoechas L.), and fennel (Foeniculum vulgare) on common foodborne pathogens. J Agric Food Chem 52(26):8255-8260

92. Lopez P, Sanchez C, Batlle R, Nerín C (2007) Vapor-phase activities of cinnamon, thyme, and oregano essential oils and key constituents against foodborne microorganisms. J Agric Food Chem 55(11):4348-4356

93. Chakraborty SB, Hancz C (2011) Application of phytochemicals as immunostimulant, antipathogenic and antistress agents in finfish culture. Rev Aquacult 3(3):103-119

94. Gyawali R, Ibrahim SA (2012) Impact of plant derivatives on the growth of foodborne pathogens and the functionality of probiotics. Appl Microbiol Biotechnol 95(1):29-45

95. Łojewska E, Kowalczyk T, Olejniczak S, Sakowicz T (2016) Extraction and purification methods in downstream processing of plant-based recombinant proteins. Prot Expr Purif 120:110-117

96. Ferreira AF, Pereira-Manfro WF, Rosa ACP (2017) Diarrheagenic Escherichia Coli and probiotic activity against foodborne pathogens: a brief review. Gastroenterol Hepatol Open Access 7(5):00248

97. Li W, Tailhades J, O'Brien-Simpson NM, Separovic F, Otvos L Jr, Hossain MA, Wade JD (2014) Proline-rich antimicrobial peptides: potential therapeutics against antibiotic-resistant bacteria. J Amino Acids 46(10):2287-2294

98. Crouzet L, Rigottier-Gois L, Serror P (2015) Potential use of probiotic and commensal bacteria as non-antibiotic strategies against vancomycin-resistant enterococci. FEMS Microbiol Lett 362(8):fnv012

99. Ringø E (2020) Probiotics in shellfish aquaculture. Aquacult Fish 5(1):1-27

100. Mohamed FM, Thabet MH, Ali MF (2019) The use of probiotics to enhance immunity of broiler chicken against some intestinal infection pathogens. SVU-IJVS 2(1):1-19

101. Shin D, Chang SY, Bogere P, Won K, Choi JY, Choi YJ, Heo J (2019) Beneficial roles of probiotics on the modulation of gut microbiota and immune response in pigs. PLoS ONE 14(8):e0220843

102. Frizzo LS, Signorini ML, Rosmini MR (2018) Probiotics and prebiotics for the health of cattle. In: Probiotics and prebiotics in animal health and food safety. Springer, Cham, pp 155-174

103. Cameron A, McAllister TA (2019) Could probiotics be the panacea alternative to the use of antimicrobials in livestock diets? Benef Microbes 10(7):773-799

104. Ren H, Vahjen W, Dadi T, Saliu EM, Boroojeni FG, Zentek J (2019) Synergistic effects of probiotics and phytobiotics on the intestinal microbiota in young broiler chicken. Microorganisms 7(12):684

105. Fang K, Jin X, Hong SH (2018) Probiotic Escherichia coli inhibits biofilm formation of pathogenic $E$. coli via extracellular activity of DegP. Sci Rep 8(1):4939

106. Hager CL, Isham N, Schrom KP, Chandra J, McCormick T, Miyagi M, Ghannoum MA (2019) Effects of a novel probiotic combination 
on pathogenic bacterial-fungal polymicrobial biofilms. MBio 10(2):e00338-e419

107. Stefańska B, Sroka J, Katzer F, Goliński P, Nowak W (2021) The effect of probiotics, phytobiotics and their combination as feed additives in the diet of dairy calves on performance, rumen fermentation and blood metabolites during the preweaning period. Anim Feed Sci Technol 272:114738

108. Kumar M, Sarma DK, Shubham S, Kumawat M, Verma V, Nina PB, Tiwari RR (2021) Futuristic non-antibiotic therapies to combat antibiotic resistance: a review. Front Microbiol 12:16
109. Ferro S, Amorico T, Deo P (2018) Role of food sanitising treatments in inducing the 'viable but nonculturable' state of microorganisms. Food Control 91:321-329

Publisher's Note Springer Nature remains neutral with regard to jurisdictional claims in published maps and institutional affiliations. 